Мельник О.П., студент V курсу магістратури факультету історії та міжнародних відносин ДВНЗ «Ужсгородський національний університет» (м. Ужгород, Украӥна)

\title{
НАПРЯМИ МОДЕРНІЗАЦЇ̈ ЗМІСТУ І ФОРМ НАВЧАЛЬНОГО ПРОЦЕСУ (З ДОСВІДУ ЗАРУБІЖНИХ УНІВЕРСИТЕТІВ)*
}

У статті зроблено спробу окреслити основні аспекти та напрями модернізаціі змісту $і$ форми навчального прочесу на основі досвіду університетів зарубіжних крайн.

Ключові слова: модернізація, вища освіта, навчальний прочес, системи альтернативного оцінювання.

The article attempts to outline the main aspects and directions of modernization of the content and form of the educational process based on the experience of universities of foreign countries.

Keywords: modernization, higher education, educational process, alternative assessment systems.

Модернізація вітчизняної вищої освіти, 3 огляду на необхідність формування інноваційної конкурентоспроможної економіки, потребує сьогодні особливої уваги. Не менш важливим є погляд на цю проблему 3 точки зору студентської молоді.

На нашу думку, серед основних напрямів такої модернізації варто виділити наступні:

1. Впровадження грантової системи як ефективного і перевіреного часом способу заохочення студентів.

2. Надання можливостей для самореалізації студентської молоді.

3. Перехід від індивідуальної до колективної системи роботи студентів та іiї оцінювання.

4. Впровадження системи рейтингу курсу.

5. Впровадження системи альтернативного оцінювання.

6. Кардинальна зміна змісту навчальних програм, пріоритетів у виборі дисциплін.

\footnotetext{
* При підготовці матеріалу використано власні дослідження автора та результати опитування студентів таких університетів: Bergische Universität Wuppertal (Німеччина); Gazi Üniversitesi (Туреччина); Rīgas Tehniskā universitāte (Латвія); Wirtschaftsuniversität Wien (Австрія); Universitat de València (Іспанія); Universitat de Barcelona (Іспанія); Универзитет «Гоце Делчев», Штип (Македонія); University of Ljubljana (Словенія); Université de Technologie de Compiègne (Франція); Akademia Polonijna w Częstochowie (Польща); Technická Univerzita v Košiciach (Словаччина).
} 
7. Розширення формату лекційних занять.

Впровадження грантової системи. Незважаючи на високу резонансність питання про скасування стипендій, оцінка релевантності цього виду заохочень говорить сама за себе. Надання фінансової допомоги кожному, хто навчається у ВН3, за дотримання формальностей відвідування занять та успішного складання сесії - виглядає дещо дивно. Практика зарубіжних колег підтверджує, що гранти, на відміну від стипендій, стимулюють прогрес у науковому середовищі, в той час як стипендії дозволяють більшій кількості студентів навчатись у вишах. У разі, якщо освіта ставить за мету якісне розширення конкурентного наукового середовища, що, в свою чергу, 3 часом приведе до підвищення рівня підготовки, то система грантів має розглядатись як пріоритетна. Якщо ж виш

ставить за мету збільшення кількості студентів, тоді скасування стипендій автоматично результуватиме у зменшення цієї кількості.

Підтримка самореалізацї студентів. Колеги 3 Туреччини та Німеччини поділились інформацією про те, що їх альма-матер надає відкритий доступ до студентських лабораторій для проведення експериментів, дослідів, розроблення програм тощо. Звісно, цей процес відбувається під наглядом фахівців. 3 огляду на те, що в Україні сам факт наявності лабораторій зазвичай викликає сумніви, варто спробувати отримати певні гранти для придбання обладнання для них. Очевидним плюсом цього $\epsilon$ можливість набути практичні навички, не відриваючись від навчального процесу, а також розвивати творче мислення і підвищувати загальний рівень інтелектуальної конкуренції.

Колективна робота студентів. Від радянської системи освіти Україна успадкувала повний індивідуалізм як в оцінюванні, так і в роботі зі студентами. Практика зарубіжних колег показала, що постійна робота в командах не тільки поліпшує безпосередні результати роботи, але й значно підвищує соціальні навички.

\section{Позитиви колективної роботи студентів:}

1. Плюралізм думок як дієвий спосіб підвищення результатів та розвитку аналітичного мислення.

2. Значне пришвидшення процесу синтезу результатів розумової діяльності шляхом ефективного робочого навантаження.

3. Стимулювання розвитку навичок співпраці та взаєморозуміння.

4. Загострення відчуття відповідальності за власні помилки через можливість зашкодити не тільки собі, а й колегам.

5. Значне зменшення навантаження для викладача під час підбиття підсумків, а отже, пришвидшення навчального процесу.

\section{Виклики колективної роботи студентів:}

1. Високі вимоги до самоорганізації членів робочої групи, загроза неефективного розподілу відповідальності та обсягу робіт. 
2. Складність формування спільного бачення щодо вирішення поставленої перед групою проблеми.

3. Колективна відповідальність за виконану роботу, звідси- можливість отримання несправедливої оцінки через непропорційний внесок членів робочої групи у загальний результат.

4. Висока гнучкість в оцінюванні з боку викладача, особливо стосовно творчих проектів.

Отже, цей вид модернізації можливий тоді, коли студенство $є$ мотивованим до його запровадження, інакше це призведе до виникнення нетерпимості до колег і загострення негативних настроїв, що своєю чергою знизить загальний рівень наукового середовища.

Впровадження системи рейтингу курсу. Це одна 3 найбільш ефективних технологій для стимулювання студентства до роботи, як і високий професіоналізм викладачів в оцінюванні здійсненої студентами роботи. Впровадження технологій складається з трьох основних етапів:

1. Розроблення системи коефіцієнтів для кожного предмета, для діяльності поза навчанням, яка безпосередньо стосується наукової (дебати, науково-практичні конференції тощо):

2. Визначення критеріїв оцінювання роботи студентів задля уникнення як необ'єктивності з боку викладачів, так і нарікань з боку студентів:

3. Впровадження системи в межах курсу (факультету або університету).

Результатом впровадження зазначеної системи буде, насамперед, стимулювання наукової діяльності студентів, окрім цього, у разі, якщо ВНЗ проводить відкриту політику щодо формування рейтингів, це дозволить їм обслуговувати інтереси роботодавців, а також допомагати формувати групи серед студентів протягом навчального процесу.

Система альтернативного оцінювання. Поширена в Україні система складання заліків та екзаменів у формі усного чи письмового «зчитування» знань студента не є адекватною стосовно багатьох дисциплін. Альтернативне оцінювання в Німеччині, Франції та Іспанії передбачає можливість проходження практики з цієї дисципліни на підприємстві, або ж розроблення

певної технології для підприємства в межах дисципліни. Після закінчення цього розроблення підприємство готує рецензію на виготовлений продукт, що виступає основним джерелом для оцінювання роботи студента або групи студентів.

Альтернативне оцінювання в Латвії, Македонії, Польщі, Словаччині та Туреччині передбачає можливість або складання класичного іспиту в усній чи письмовій формі, або підготовки глибокого дослідження з дисципліни. Під глибоким дослідженням розуміється узгоджена 3 викладачем тема, яка охоплює вузький аспект дисципліни. Це дозволяє оцінити не лише рівень загальних знань, а й ефективність наукової діяльності студента або групи студентів. 
Розиирення формату лекційних занять. Досить поширеною практикою в українських ВНЗ є викладання непрофільних предметів на всіх факультетах, до того ж різними фахівцями. Такого роду діяльність не має взагалі наукового сенсу, завантажує студентів і зазвичай закінчується частковою або повною відсутністю їх на парах. Колеги 3 Німеччини використовують іншу систему лекційних занять. Кожен викладач розробляє власні курси 3 дисциплін, які $б$ він хотів запропонувати студентам, i виставляє їх у загальний розклад. Відповідно студенти самі обирають, до якого викладача їм варто ходити. Інакше кажучи, якщо кілька викладачів запропонують викладання дисципліни «Політологія», то відвідуваність студентів якраз і слугуватиме індикатором якості і цікавості цього курсу. Окрім цього, зазначене дозволить не дублювати у розкладі по кільканадцять разів один і той самий предмет, закріплюючи його за різними викладачами. Безперечно, така модифікація приведе до зменшення навантаження для викладачів і скорочення їх кількості, але питання якості вищої освіти має бути пріоритетним.

Зміна структури навчальних програм. Для здобуття ОКР «Бакалавр» у зарубіжних вишах використовується система «16 плюс 12», що включає 16 профільних дисциплін і 12 додаткових. Зазвичай студентам пропонують близько 30 додаткових дисциплін, з яких варто обрати лише 12. Профільні дисципліни складаються шляхом розроблення проектів, наукових досліджень або інших методів, запропонованих вище, і не включають лекційних занять. Інакше кажучи, студенти курсу «Політологія» будуть відвідувати лекційні заняття (описані вище) загального характеру, і саме практична діяльність слугуватиме критерієм і підставою для оцінювання знань. Відповідно додаткові предмети -це спецкурси, які не мають профільного характеру, але вважаються такими, що безпосередньо стосуються курсу.

Окрім цього, складати предмети можна у довільному порядку, не існує сталої черговості цього процесу (щоправда, існує рекомендована). Кожен предмет має індивідуальні терміни складання, тобто не протягом одного семестру, а, наприклад, 9 тижнів, або навпаки - 30 тижнів (приблизно півтора року). Така гнучка система дозволяє студентам самотужки формувати навантаження і максимально ефективно використовувати власні ресурси.

Щодо додаткових спецкурсів, то зазвичай вони являють собою 2-5тижневі курси 3 дуже щільним графіком, великим навантаженням та читаються протягом неускладненої частини семестру.

Скласти будь-який предмет можна протягом усього терміну навчання. Тобто, прослухавши курс «Політологія», скласти його можна і через два роки. Така гнучка система більш актуальна на технічних спеціальностях, оскільки розроблення певного проекту не завжди можливе в межах відведеного на дисципліну часу.

Окрім цього, під час навчання можна проходити різні програми сертифікації в межах вузу, що зазначаються в додатку до диплома. Ці 
програми дозволяють як розширити кваліфікацію, так i звузити спеціалізацію, більш точно відображаючи професійне спрямування студента.

Розвиток структури університету на принципах самоорганізації. Принцип побудови управлінської та наукової ієрархї університету дуже індивідуальний, зазвичай продиктований особливостями самих ВНЗ. Попри це, можна сформувати кілька напрямів, які можуть зазнати потенційної модернізації. Це:

1) Студентське самоврядування.

2) Розподіл організаційних повноважень між студентами та викладачами.

\section{Студентське самоврядування}

Студентське самоврядування - одна з розвинених сфер у вищій освіті України. Багато в чому українці тут випереджають зарубіжних колег, але варто зазначити, що нам також цікаво було б перейняти досвід у деяких аспектах, зокрема:

1. Змінити підхід до вибору представників в актив студентської громади. В Україні зазвичай ними виступають студенти старших курсів, а саме 3-4 року навчання, іноді студенти першого курсу магістратури. Такого роду підхід дозволяє швидко знаходити спільну мову 3 керівництвом вузу, проводити численні заходи, але водночас ускладнює можливість тривалого розвитку відносин. Між тим у Латвії, Македонії та Туреччині пріоритетним контингентом для набору виступають саме перші курси, оскільки наявність великої кількості вільного часу i, зазвичай, відсутність позауніверситетської активності дозволятиме реалізувати себе в громаді. Основними позитивами виступають висока мотивованість, можливість постійно організовувати різного роду заходи, формування факультативних занять тощо.

2. Винагорода за участь у студентській громадській діяльності. В Україні винагорода за таку участь завжди умовна і повністю залежить від лояльності викладачів. Саме тому ентузіазм членів громади швидко вичерпуватиме себе, адже участь в організації заходів будь-якого характеру потребує багато сил і часу. У вищезгаданих країнах для заохочення

участі використовують різні методи, зокрема такі, як:

1) додаткові бали до рейтингу (Туреччина);

2) спрощена система доступу до лабораторій (Туреччина);

3) можливість організації різноформатних конференцій, дебатів серед студентства $з$ активним залученням викладачів (Македонія, Латвія);

4) пріоритетність при відборі до участі в міжнародних програмах обміну студентами (усі країни);

5) можливість змінювати порядок складання сесії у разі збігу графіка заходів громади (Латвія).

Інакше кажучи, участь у громадському житті дозволятиме студенту більш гнучко використовувати ресурси університету в обмін на його час та активність. 


\section{Розподіл організаційних повноважень між студентами та викладачами}

Завдяки високій активності студентської громади у зарубіжних колег сформувались додаткові напрями співпраці між студентами та викладачами.

Це зокрема:

1. Конференції та дебати. В Латвії та Македонії, на противагу класичним семінарським заняттям, пропонують постійно проводити різні дебати або конференції студентів для зіткнення думок, поглядів тощо.

2. Факультативні заняття студентів. Багато викладачів готові проводити додаткові лекції для студентів 3 проблематики, які цікавлять будь-яку із сторін. Саме активність студентської громади та ентузіазм викладачів дозволяють доповнювати навчальний процес факультативними заняттями, конференціями, дебатами тощо.

3. Позауніверситетські заходи. Те, що варто перейняти від зарубіжних колег, - це вечірки студентів і викладачів. Вони поширені у Словаччині, Німеччині, Франції та Іспанії. Наприклад, щотижня відбувається вечірка, організована студентами по обміну, - «Іспанський вечір», «Італійський вечір» тощо. Такі заходи допомагають створювати колектив зі студентів i викладачів, однак, попри стереотипи, тільки поліпшують відносини в стінах аудиторії, оскільки студенти ніколи не дозволяють собі переходити межу між професійним та особистим. Окрім цього, самі викладачі відзначають, що можливість пізнати студентів як особистість дозволяло легше знаходити до них підхід, у загальному підвищуючи продуктивність спільної роботи.

4. Анонімні характеристики. Їх практикують самі викладачі, пропонуючи студентам в аудиторії дати їм анонімну характеристику, наголосити на помилках, сформувати побажання для того, щоб викладач зміг поліпшувати свою співпрацю зі студентами. Така процедура дуже специфічна. Оскільки викладачі 3 низьким рівнем самокритики або безвідповідальні студенти здатні при цьому погіршити стосунки, тому таку характеристику пропонують написати після закінчення курсу, щоб особисті погляди не завадили оцінюванню.

5. Запрошення третьої сторони - один 3 цікавих способів проведення семінарів у Латвії та Македонії. Для проведення заняття запрошують представників з різних сфер, які добре обізнані з проблематикою проведення дискусії зі студентами. Зазвичай активна підтримка з боку громади лише примножуватиме кількість таких фахівців, робитиме навчальний процес більш цікавим та багатогранним, не обмежуючи його лише співпрацею викладачів та студентів. 